\title{
First Report of Field Remediation of Contaminated Tailings from the Collapsed Fundão Dam in Brazil
}

\author{
Maria Rita Scotti ${ }^{1}$, Stephania S Avila1, Leonardo Mendes ${ }^{1}$, Tomas. J. Lacerda ${ }^{1}$, Samuel Lourenço L. \\ Silva1, Arthur C Antão1, Alessandra R. F Gomes ${ }^{1}$, Mirelli B Medeiros ${ }^{2}$, Stael Alvarenga ${ }^{2}$, Carlos \\ Henrique B Santos ${ }^{3}$, Everlon C Rigobelo ${ }^{3}$
}

\author{
${ }^{1}$ Depto de Botânica/ICB/UFMG \\ Av Antonio Carlos 6627, Belo Horizonte, Brasil \\ mrsm.ufmg@gmail.com \\ ${ }^{2}$ Escola de Arquitetura /UFMG Programa Pós Graduação em Ambiente Construído e Patrimônio Sustentável \\ Av Antonio Carlos 6627, Belo Horizonte, Brasil. \\ ${ }^{3}$ Dept. Produção Vegetal/ Universidade do Estado de São Paulo /Unesp \\ Via Professor Paulo Donato Castelane Castellane S/N - Vila Industrial, 14884-900 Jaboticabal, Brasil.
}

\begin{abstract}
The failure of the Fundão dam in Brazil spilled contaminated sediments to the Doce river basin with high levels of $\mathrm{pH}$,ether-amine and sodium. In the present study, it was established a riparian forest over contaminated sediment using two main remediation strategies: phytoremediation with native species to the Atlantic Forest, previously selected for tolerance to the sediment toxicity, and physico-chemical remediation by management of the sediment with incorporation of OM. In the experimental site (ES), 12 native species were cultivated under two treatments: T1- management of the sediments with incorporation of OM and T2- nonmanaged sediment + superficial deposition of OM. The results were compared with a degraded site (DS) affected by the contaminated sediments and a preserved site (PS) composed of a fragment of preserved Atlantic Forest. After 6 month of transplanting, plants from $\mathrm{T} 1$ showed a better height growth performance (up to $3 \mathrm{~m}$ ) and survival index in relation to T2, as well as a significant decline of ether- amine and sodium contents. Besides the improvement of soil fertility, the amendment with OM promoted a pH reduction, favoring ether-amine destabilization, sodium sequestration and improvement of soil microbial populations. Soil nitrification was improved as revealed by the significant increase of nitrate which seems to have favoured the rampant growth of tolerant plant species after 6 months of planting. Therefore, it is recommended the incorporation of OM to the sediment and phytoremediation with selected tolerant species to remediate sodium and ether-amine toxicity.
\end{abstract}

Keywords: Dam tailings, Ether-amine, Sodium, pH, Phytoremediation, Reclamation.

\section{Introduction}

The failure of the Fundão dam which belonged to the mining company Samarco S/A and was located in the Mariana town (Brazil), has spread a sediment wave that reached the Doce River basin until the Atlantic Ocean, constituting the largest environmental disaster in Brazil [1].

The main environmental impact of this dam rupture has been attributed to the elevated amounts of ether-amine and sodium as well as the high $\mathrm{pH}$ found in the sediments as compared to preserved sites not reached by the tailings [2]. Ether-amines and $\mathrm{NaOH}$ are products that were found into the dam and derived from the Reverse Cationic Flotation technique used in iron ore benefitiation process by Samarco mine [3,4,5]. The toxic effects of ether amines and sodium in the reached zones [2] have been associated with plant mortality and a strong decline of microbial populations and diversity $[2,6]$.

Therefore, the aim of this study was to assess physico-chemical and phyto-remediation procedures to reclaim ether-amine and sodium toxicity under field conditions.

\section{Material and methods}

\subsection{Study site}

The study sites consisted of the following riparian sites: 1- Preserved site (PS) located along the Lavras Velhas river $\left(20^{\circ} 20^{\prime} 3134^{\prime \prime} \mathrm{S} 43^{\circ} 17^{\prime} 13.61^{\prime \prime} \mathrm{W}\right)$, 2- Degraded Site (DS) located in the Gualaxo river, reached by the dam tailings $\left(20^{\circ} 17^{\prime} 55.79^{\prime \prime S} 43^{\circ} 14^{\prime} 07.31^{\prime \prime} \mathrm{W}\right)$ and a 3- Experimental Site (ES) located in the same river where the remediation procedures were installed over a $2 \mathrm{~m}$ sediment layer (Fig 1). 


\subsection{Experimental design}

The design of ES in a area of $1500 \mathrm{~m}^{2}(60 \mathrm{~m} \times 25 \mathrm{~m})$ was composed of 2 blocks with 2 plots/treatment $(15 \times 25 \mathrm{~m})$ and 2 treatment/block .The remediation treatments were: T1- Plant-derived organic matter (OM) incorporation to scrapped sediment (top layer) and T2- intact sediment plus superficial deposition of OM. The OM used in ES was composed of Ca: $1.28 \%, \mathrm{P}: 0.22 \%, \mathrm{~K}: 2.1 \%, \mathrm{Mg} 0.3 \%, \mathrm{~N}: 2.1 \%, \mathrm{C} / \mathrm{N} 24$ and with $\mathrm{pH} 5$. Itwas added $50 \mathrm{~kg} / \mathrm{plot}$ in a proportion of 1:4(vv).

Each plot was cultivated with 12 Atlantic forest species, which were previously selected for tolerance to the sediment. The plants were transplanted to the field after 4 months growing under nursery conditions with a spacing of 3 x $3 \mathrm{~m}$. It was established four plots of $375 \mathrm{~m}^{2}(15 \times 25 \mathrm{~m})$ in the reference sites DS and PS.

Therefore, three remediation strategies were used: 1- Phytoremediation using selected plant species tolerant to the sediment toxicity under green-house conditions; 2- Physico-chemical remediation by management of the sediment with incorporation of $\mathrm{OM}$ to reduce ether-amine and sodium toxicity, besides lowering $\mathrm{pH}$.

\subsection{Soil analysis}

Samples were obtained from 0 to $20 \mathrm{~cm}$ depth, at each study site (ES, DS and PS). In ES, 16 samples or 8 mixed samples/treatment ( 2 mixed soil samples/plot/treatment $\times 2$ treatments $\times 4$ plots) were collected 6 months after transplantation. In DS and PS, 8 samples were collected composed of 2 mixed soil samples/plot/site x 4 plots. The soil chemical analysis was performed according to EMBRAPA [2]. Total inorganic nitrogen was determined by semimicroKjeldahl digestion [8] and ammonium and nitrate contents were determined according to Bremner and Keeney [9]. Etheramine quantification was performed using the colorimetric bromocresol green method [2,10]. Total microbial biomass was determined by total phospholipid fatty acids (PLFA) analysis [2].

\section{Results and Discusion}

Using the sediment spilled from the dam, contaminated with ether-amines and sodium [2], we performed a screening test, resulting in the selection of native species to the Brazilian Atlantic Forest with a varying tolerance degree, to be tested in the field. Under field conditions, the plants showed a higher survival index in T1 (84\%) than T2 (61\%), and the height growth in T1 was nearly twice that observed in T2 ( Table 1 ). Therefore, the combined treatment of sediment scrapping associated with its mixture with plant-derived OM favored the establishment and survival of native plants in the field, which showed an outstanding growth performance only 6 months after transplanting. The better growth performance of native plants observed in T1 may be attributed to the greater reduction of sodium and ether-amine in comparison to T2 and both in relation to DS (Table 2), as a consequence of the physico-chemical (sediment management + OM incorporation) remediation procedure.

Ether-amine concentrations reached levels as low as those from the PS as did the soil ammonium content. Such reductions may be attributed to both the physico-chemical and phytoremediation procedures. Considering that there was a decrease of $\mathrm{N}$-ammonium concomitant with an increase of $\mathrm{N}$-nitrate in ES, we may conclude that the plants may have used the ammonium derived from ether-amine degradation [11]. Indeed, the $\mathrm{pH}$ reduction by the $\mathrm{OM}$ amendment leads to ether-amine destabilization since the ionization of secondary and tertiary amines greatly depends on $\mathrm{pH}$ levels [12]. Under alkaline $\mathrm{pH}$ conditions ( $\sim 9)$, ether-amine shows low dissociation capacity and solubility, while in $\mathrm{pH} \sim 5$, it becomes dissociated and soluble in aqueous solution [11]. Therefore, the reduction of soil $\mathrm{pH}$ using OM amendment with $\mathrm{pH} 5$ was also proposed to favor the ether-amine dissociation, increasing its availability to biodegradation [11] and further utilization for plant growth as $\mathrm{N}$ source. Additionally, the $\mathrm{OM}$ favoured the oxidation of ammonium to nitrate by the nitrifying microbial community since there was a marked increase of both soil microbial biomass and nitrate in ES, especially in T1 in relation to DS. Besides, the $\mathrm{N}$ derived from the OM itself may be considered another source of $\mathrm{N}$. Thus, such increased nitrate levels in ES may have largely contributed to the outstanding plant growth, highlighting in T1.

Sodium levels also declined in ES, mainly in T1 but still showed significantly higher levels than PS (Table 2). Sodium reduction may be attributed to the physico-chemical remediation procedure since the OM shows chelating properties [13,14], whose acidic characteristics [15] improve the negative charges able to hold the Na ions. Thus, the decrease of $\mathrm{pH}$ promoted by the $\mathrm{OM}$ amendment associated with the $\mathrm{Na}$ decline reinforce the idea of the Na chelating properties of $\mathrm{OM}[13,14,16]$. In fact, there was a greater reduction of $\mathrm{Na}$ in $\mathrm{T} 1$ where the $\mathrm{OM}$ was incorporated to the sediment in comparison to $\mathrm{T} 2$ where it was deposited in the superficial layer, thus, becoming more exposed to superficial erosion and runoff.

The incorporation of SOM to the sediment also resulted in an overall increase in soil fertility in T1 than T2, as determined by the increase of $\mathrm{K}, \mathrm{Ca}, \mathrm{Mg}$ and $\mathrm{P}$ (Table 2). Such increase in soil fertility in ES, particularly in T1, may 
likely be attributed to the incorporation of organic matter to the topsoil, becoming it more homogeneously distributed in a thicker sediment layer than the superficial deposition in T2. In consequence, it resulted in a reduction of nutrients losses or a better physical contact of plant root and nutrients.

\section{Conclusion}

This is the first report of field remediation of contaminated sediments from the Fundão dam rupture. In other to reclaim $\mathrm{Na}$ and ether-amine toxicity, we first selected tolerant plant species able to growth on the contaminated sediment. Second, we proposed physical, chemical and phyto-remediation procedures under field conditions. The physico-chemical remediation consisted in the incorporation of $\mathrm{OM}$ to the sediment which promoted $\mathrm{pH}$ reduction, favoring the $\mathrm{Na}$ decline, ether-amine destabilization and soil fertility improvement as well as the increase of microbial communities. Under this treatment, selected tolerant plant species showed a rampant growth only 6 months after planting.

A

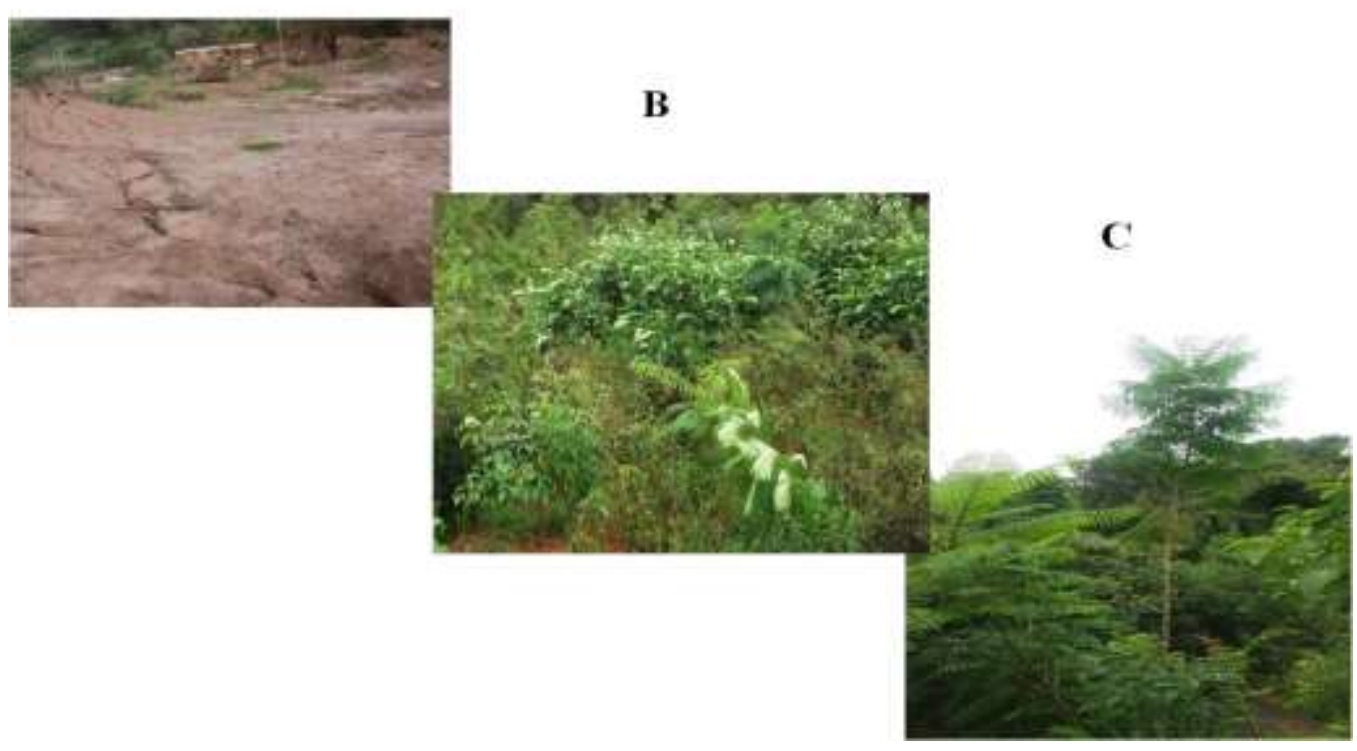

Fig. 1: A: disturbed Site before transplantation, B: Experimental site (ES) 6 months and C: ES 12 months after transplantation.

Table 1: Survival index and height growth of plants cultivated in the experimental site (ES) under treatments 1 (ES T1) and 2 (EST2). The variance of analysis (ANOVA ${ }^{1}$ was applied to compare mean differences among sites (significance at $\mathrm{p} \leq 5 \%$ ). Tukey test.

ES T1

ES T2

\section{Survival (\%)}

$84,3^{\mathrm{a}}$

$61,4^{\mathrm{a}}$
Height mean (m)

$2,0^{\mathrm{b}}$

$1,1^{\mathrm{b}}$ 
Table 2: Soil chemical analysis, ether-amine content and total microbial biomass in Experimental site (ES) uunder two management treatment ( ES-T1 and ES-T2) as compared to preserved (PS) and disturbed (DS).sites . The variance of analysis (ANOVA1 was applied to compare mean differences among sites (significance at $\mathrm{p} \leq 5 \%$ ). Tukey test.

\begin{tabular}{|c|c|c|c|c|c|c|c|c|c|c|c|}
\hline & $\begin{array}{l}\text { Soil } \\
\text { pH }\end{array}$ & $\begin{array}{c}\mathrm{K} \\
(\mathrm{mg} / \mathrm{k})\end{array}$ & $\begin{array}{c}\mathrm{Ca} \\
(\mathrm{mg} / \mathrm{kg} \\
)\end{array}$ & $\begin{array}{c}\mathrm{Mg} \\
(\mathbf{m g} / \mathbf{k g})\end{array}$ & $\begin{array}{c}\mathbf{P} \\
(\mathbf{m g} / \mathbf{k g})\end{array}$ & $\begin{array}{l}\text { N-NO3- } \\
\text { (mg/kg) }\end{array}$ & $\begin{array}{l}\text { N-NH4 } \\
(\mathrm{mg} / \mathrm{kg})\end{array}$ & $\begin{array}{l}\text { OM } \\
(\%)\end{array}$ & $\begin{array}{c}\mathrm{Na} \\
(\mathrm{mg} / \mathrm{k} \\
\mathrm{g})\end{array}$ & $\begin{array}{l}\text { Ether- } \\
\text { amine } \\
\text { (mg/kg) }\end{array}$ & $\begin{array}{l}\text { Microbial } \\
\text { biomass - } \\
\text { C ( nmol/ } \\
\text { g) }\end{array}$ \\
\hline PS & $4,5^{\mathrm{a}}$ & $73,8^{\mathrm{a}}$ & $274^{\mathrm{a}}$ & $72,3^{\mathrm{a}}$ & $6,57^{\mathrm{a}}$ & $42,80^{\mathrm{a}}$ & $6,50^{\mathrm{a}}$ & $8,7^{\mathrm{a}}$ & $4,8^{\mathrm{a}}$ & $0^{\mathrm{a}}$ & $137^{\mathrm{a}}$ \\
\hline DS & $8^{d}$ & $8^{c}$ & $182^{\mathrm{b}}$ & $10,1^{\mathrm{c}}$ & $4,8^{\mathrm{c}}$ & $1,80^{\mathrm{d}}$ & $3,40^{\mathrm{c}}$ & $0,96^{\mathrm{c}}$ & $54,1^{\mathrm{c}}$ & $6,1^{\mathrm{d}}$ & $1,53^{\mathrm{d}}$ \\
\hline $\begin{array}{l}\mathbf{E S} \\
\mathbf{T 1}\end{array}$ & $5,9^{\mathrm{b}}$ & $38,8^{\mathrm{b}}$ & $327,8^{\mathrm{a}}$ & $48,8^{\mathrm{b}}$ & $11,8^{\mathrm{ab}}$ & $33,40^{\mathrm{bc}}$ & $2,00^{\mathrm{b}}$ & $1,82^{\mathrm{ab}}$ & $22,6^{b}$ & $0,37^{\mathrm{b}}$ & $26,7^{\mathrm{b}}$ \\
\hline $\begin{array}{l}\text { ES } \\
\text { T2 }\end{array}$ & $6,5^{\mathrm{c}}$ & $18,7^{\mathrm{b}}$ & $252,5^{\mathrm{a}}$ & $24^{\mathrm{b}}$ & $10,5^{\mathrm{b}}$ & $17,90^{\mathrm{c}}$ & $2,30^{\mathrm{b}}$ & $0,99^{\mathrm{bc}}$ & $30,5^{b}$ & $0,72^{\mathrm{c}}$ & $13,7^{\mathrm{c}}$ \\
\hline
\end{tabular}

\section{References}

[1] D. L. Silva, M. C. Ferreira, and M. R. Scotti, "O maior desastre ambiental brasileiro: De Mariana (MG) a Regência (ES),” Arq. Mus. Hist. Nat. Jardim Bot., vol. 157, pp. 136-158, 2015.

[2] O. S. H. Santos, F. C. Avellar, M. Alves, R. C. Trindade, M. B. Menezes, M. C. Ferreira, G. S. França, J. Cordeiro, F. G. Sobreira, I. M. Yoshida, P. M. Moura, M. B. Baptista, and M. R. Scotti, "Understanding the Environmental Impact of a Mine Dam Rupture in Brazil: Prospects for Remediation,” J. Environ. Qual., vol. 48, pp. 439-449, 2019.

[3] A. C. Araujo, P. R. M. Viana, and A. E. C. Peres, "Reagents in iron ores flotation," Miner. Eng., vol. 18, pp. 219224, 2005.

[4] G. M. B. Batisteli, “Amina residual na flotação catiônica reversa de minério de ferro," MS dissertation, Dep Eng Mine Univ. Fed. Minas Gerais, Belo Horizonte, Minas Gerais, Brazil, 2007.

[5] O. B. Reis, "Estudo preliminar sobre reciclagem das aminas utilizada em flotação de minério de ferro," MS dissertation, Dep Eng Mine. Univ. Fed. Ouro Preto, Ouro Preto, Minas Gerais, Brazil, 2004.

[6] F. R. Segura, E. A. Nunes, F. P. Paniz, A. C. C. Paulelli, G. B. Rodrigues, G. U. L. Braga, et al. "Potential risks of the residue from Samarco's mine dam burst (Bento Rodrigues, Brazil)," Environ. Pollut., vol. 218, pp. 813-825. 2016.

[7] EMBRAPA, Manual de métodos de análise do solo. EMBRAPA, Rio de Janeiro, 1997.

[8] J. M. Bremner, "Determination of nitrogen in soil by the Kjeldahl method," J. Agric. Sci., vol. 55, pp. 11-33, 1960.

[9] J. M. Bremner and D. R. Keeney, "Stem distillation methods for determi $\neg$ nation of ammonium, nitrate and nitrite," Anal. Chim. Acta, vol. 32, pp. 485-495, 1965.

[10] D. M. Araújo, M. I. Yoshida, and C. F. Carvalho, "Colorimetric determination of ether amine greases utilized in the flotation of iron ore," J. Anal. Chem., vol. 64, pp, 390-392, 2009.

[11] D. M., Araujo, M. I. Yoshida, J. A. Takahashi, C. F. Carvalho, and F. Stapelfeldt, "Biodegradation studies on fatty amines used for reverse flotation of iron ore," Int. Biodeterior. Biodegradation, vol. 64, pp. 151-155, 2010.

[12] M. C. Fuerstenau, J. D. Miller, and M. C. Kuhn, Chemistry of Flotation. Soc of Mining Engineers of AIME, New York, USA, 1985.

[13] A. Lax, E. DõÂaz, V. Castillo, and J. Albaladejo, "Reclamation of physical and chemical properties of a salinized soil by organic amendment," Arid Soil Research and Rehabil., vol. 8, pp. 9- 18, 1994.

[14] C. W. Robbins, "Sodic Calcareous Soil Reclamation as Affected by Different Amendments and Crops," Agron. J., vol. 78, pp. 916-920, 1986.

[15] E. M. Thurman, Organic geochemistry of natural waters. Kluwer Academic Academic Pub., Hingham, MA1986.

[16] A. Hanay, F. Büyüksönmez, F.M. Kızlloglu, and M. Y. Canbolat, "Reclamation of Saline-Sodic Soils with Gypsum and MSW Compost," Compost Science \& Utilization, vol. 12, no. 2, pp. 175-179, 2004. 